\title{
Examining the mechanical influences upon the sciatic nerve at the sciatic nerve- hamstring muscle interface during active and passive knee extension
}

\section{Ellis, RF. ${ }^{1}$ Fox, J. ${ }^{2}$ Hitt, JR. ${ }^{3}$ Langevin, H. ${ }^{2}$ Henry, SM. ${ }^{3}$}

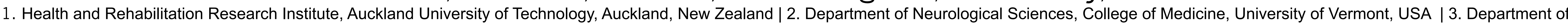
Rehabilitation and Movement Science, College of Nursing and Health Sciences, University of Vermont, USA I Contact for this poster: rellis@aut.ac.nz Acknowledgements: Sonya Worth ${ }^{3}$ and Linsey Tulipani ${ }^{3}$

\section{BACKGROUND}

Neural mobilisation exercises are designed to promote movement of peripheral nerves against interfacing tissues (mechanical interface). Previous studies have quantified peripheral nerve movement in response to joint/limb movements. However, few have examined the mechanical interaction the interfacing tissues (i.e. muscles) have upon nerve movement. This knowledge is important to aid the design and prescription of neural mobilisation exercises.

\section{OBJECTIVES}

1. To quantify sciatic nerve excursion in sitting versus side-lying during active and passive lower limb movements

2. To determine if external mechanica influences (nerve-muscle shear-strain, hamstring muscle activity) alter sciatic nerve excursion

\section{METHODS}

Controlled, observational laboratory study with 10 healthy participants (i.e. no lumbar or lumbar-related leg pain) between 18.65 yrs volunteered. Four test conditions were used:

A. Side-lying: Active and Passive knee flexion $\left(80^{\circ} \mathrm{F}\right)$ to extension $\left(20^{\circ} \mathrm{F}\right)$ back to flexion $\left(80^{\circ} \mathrm{F}\right.$ ) (Fig. $\left.1, \mathrm{~A}\right)$

B. Sitting: Active and Passive knee flexion $\left(80^{\circ} \mathrm{F}\right)$ to extension $\left(20^{\circ} \mathrm{F}\right)$ back to flexion $\left(80^{\circ} \mathrm{F}\right)$ (Fig. $\left.1, \mathrm{~B}\right)$

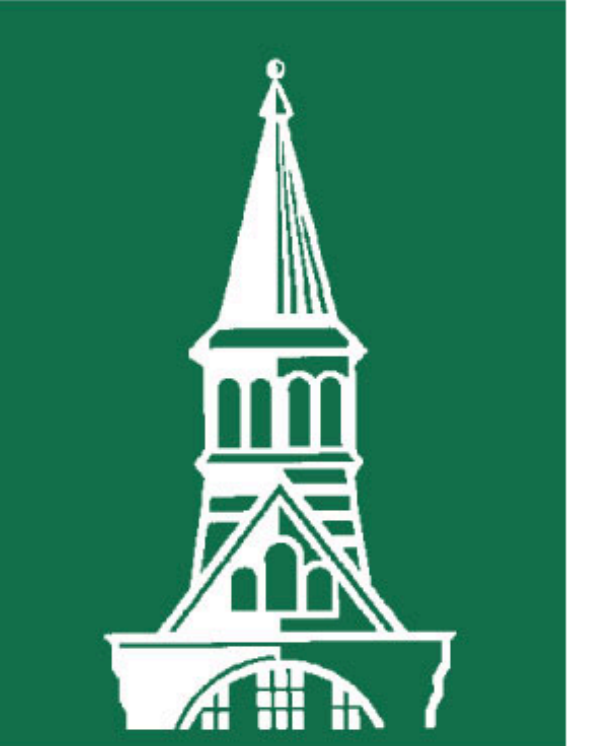

The

UNIVERSITY of VERMONT
Figure 1. Participant position

A. Side-Lying (Bird's eye view)
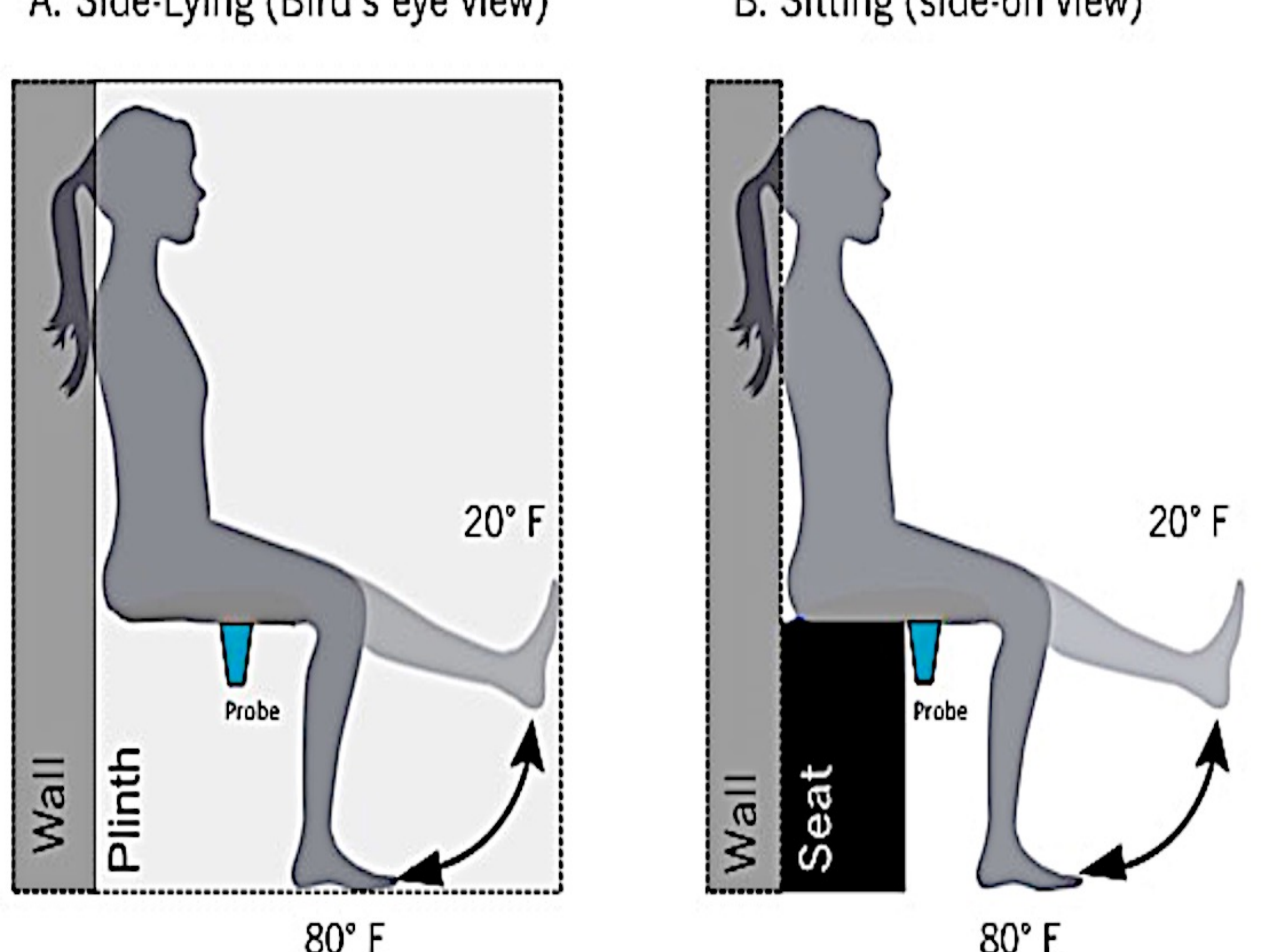

Each movement took $9 \operatorname{secs}\left(80^{\circ}-20^{\circ} \mathrm{F} 4\right.$ secs; 1 sec pause; $20^{\circ}-80^{\circ} \mathrm{F} 4$ secs) One leg randomly selected for testing. Foot held rigid in ankle-foot orthosis (plantargrade). For tested leg, Opal inertial sensors quantified lumbar spine/pelvis, femur and tibia movement $\left({ }^{\circ}\right)$ and hamstring muscle activity (EMG) in 4 epochs (Fig. 2).

Outcome measures (Fig 3):

Sciatic nerve lateral displacement $(\mathrm{mm})$ as measured with ultrasound (Fig. $3, A)$

Differential lateral displacement between sciatic nerve and hamstring interfaces $(\mathrm{mm})$. Integration of the absolute value of differential curve is total differential motion (Fig 3. B)

Sciatic nerve-hamstring muscle shearstrain (\%) as measured with ultrasound elastography (Fig. 3, C)
Figure 2. EMG and ROM example for Side-lying exercise $(n=1)$

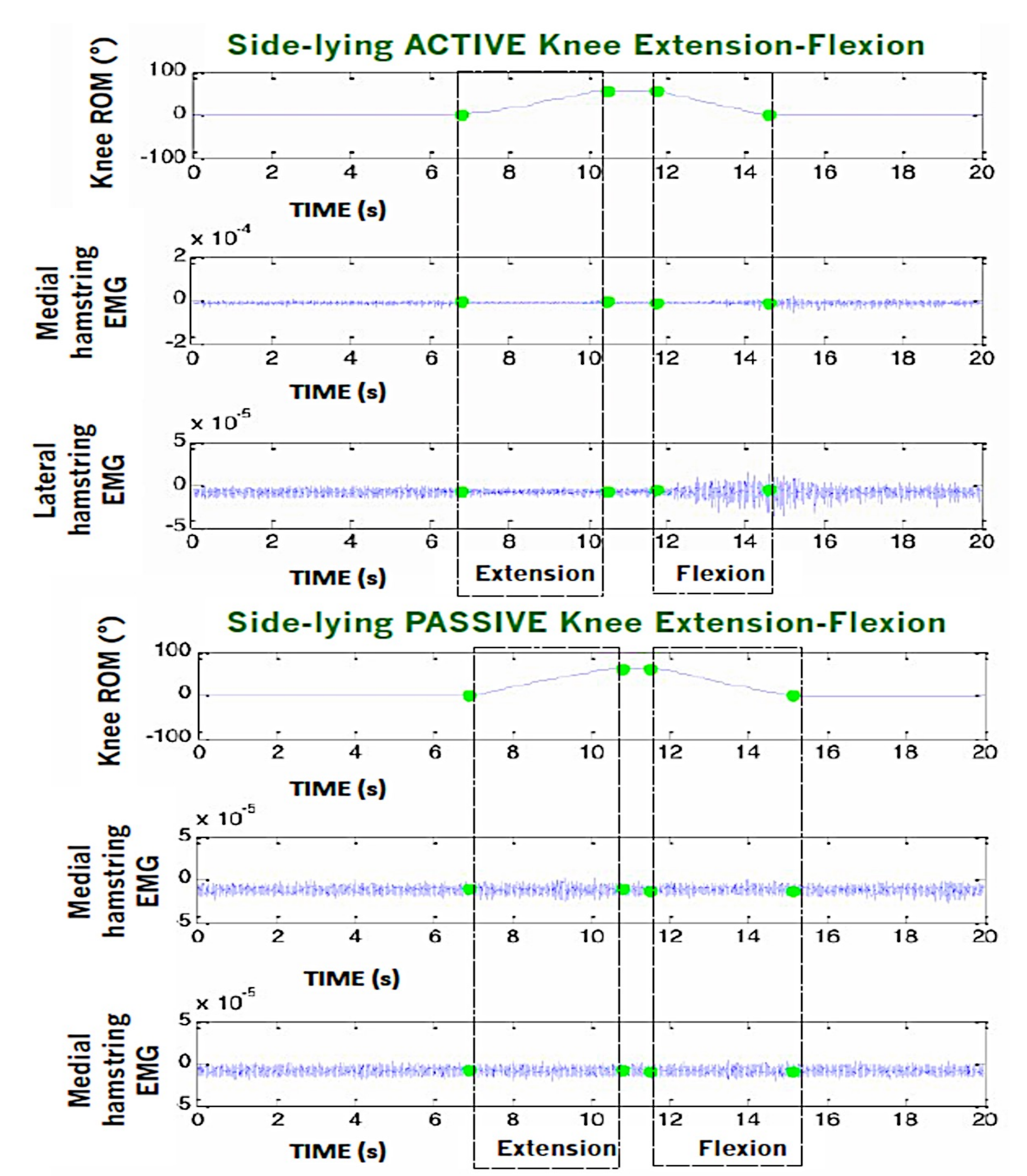

Figure 3. Outcome measures
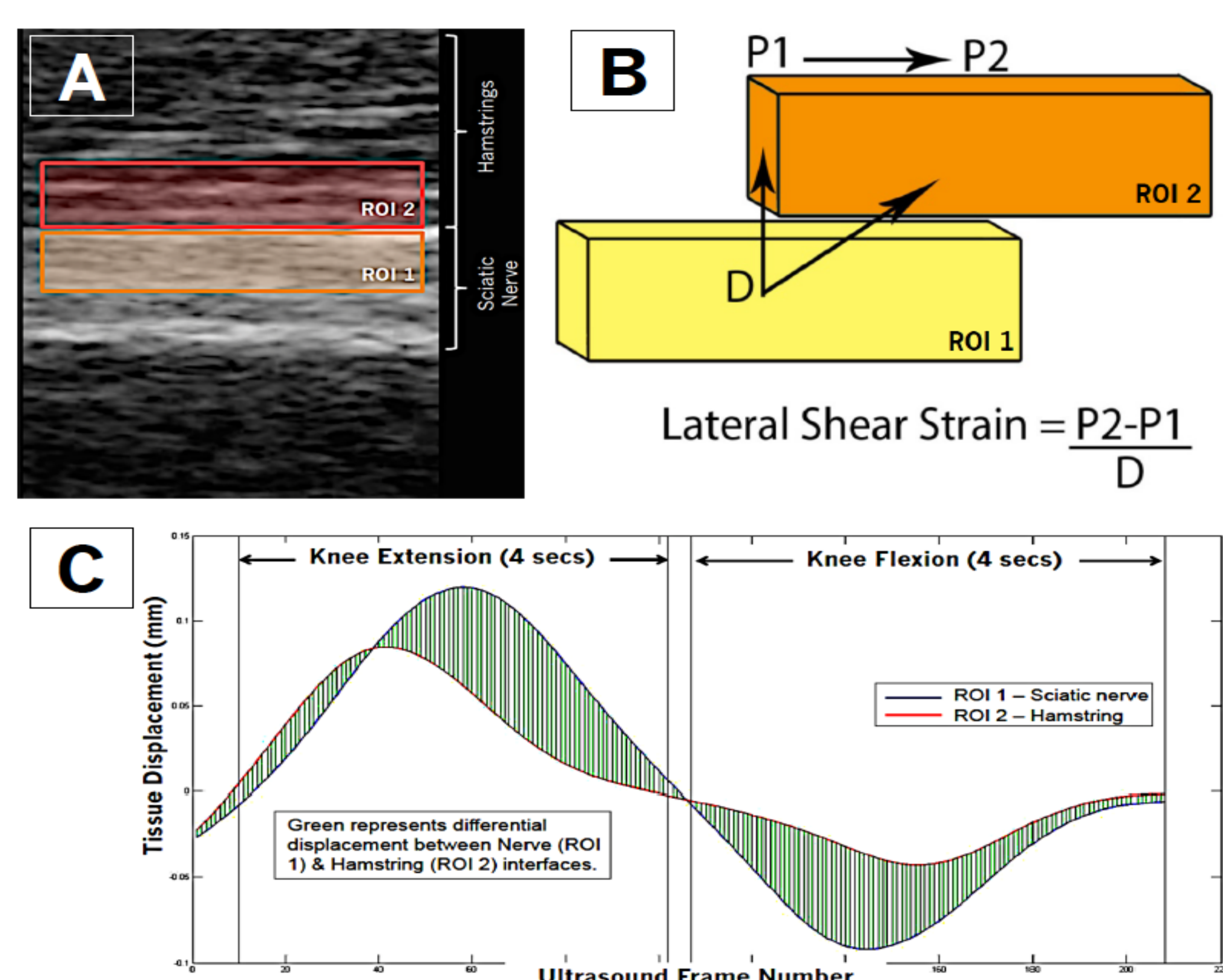

RESULTS

Although significant differences $(p<0.05)$ were seen between active vs. passive exercises, for the side-lying position these were greater for passive in contrast to active exercises for the sitting position.

\begin{tabular}{|c|c|c|c|c|}
\hline & & $\begin{array}{c}\text { Nerve } \\
\text { displacement } \\
(\mathrm{mm})\end{array}$ & $\begin{array}{l}\text { Differential } \\
\text { displacement } \\
(\mathrm{mm})\end{array}$ & $\begin{array}{c}\text { Nerve- } \\
\text { hamstring } \\
\text { shear-strain (\%) }\end{array}$ \\
\hline & & $11.7(3.9)^{*}$ & $2.9(0.9)^{*}$ & $84.02(17.8)^{*}$ \\
\hline lying & Passive & $17.4(2.9)^{*}$ & $3.8(1.9)^{*}$ & $108.8(50.9)^{*}$ \\
\hline Sitting & $\begin{array}{l}\text { Active } \\
\text { Daccivo }\end{array}$ & $\begin{array}{l}11.0(3.9)^{*} \\
86(202) *\end{array}$ & $4.7(3.0)$ & $\begin{array}{l}141.4(90.6) \\
150.68790\end{array}$ \\
\hline
\end{tabular}

Generally for both differential lateral displacement and nerve-muscle shear strain, between the sciatic nerve and hamstring interfaces, passive exercises induced greater effects. However, these differences were only statistically significant $(p<0.05)$ for the Side-lying condition.

\section{DISCUSSION/IMPLICATIONS}

For a majority of outcome measures, passive exercises resulted in the greatest effects (except for nerve displacement in sitting). When designing neural mobilisation exercises, those performed passively and in side-lying will maximise nerve displacement, however this comes at a cost with increased shear-strain (which may be best to avoid when neura tissue is mechanosensitised).

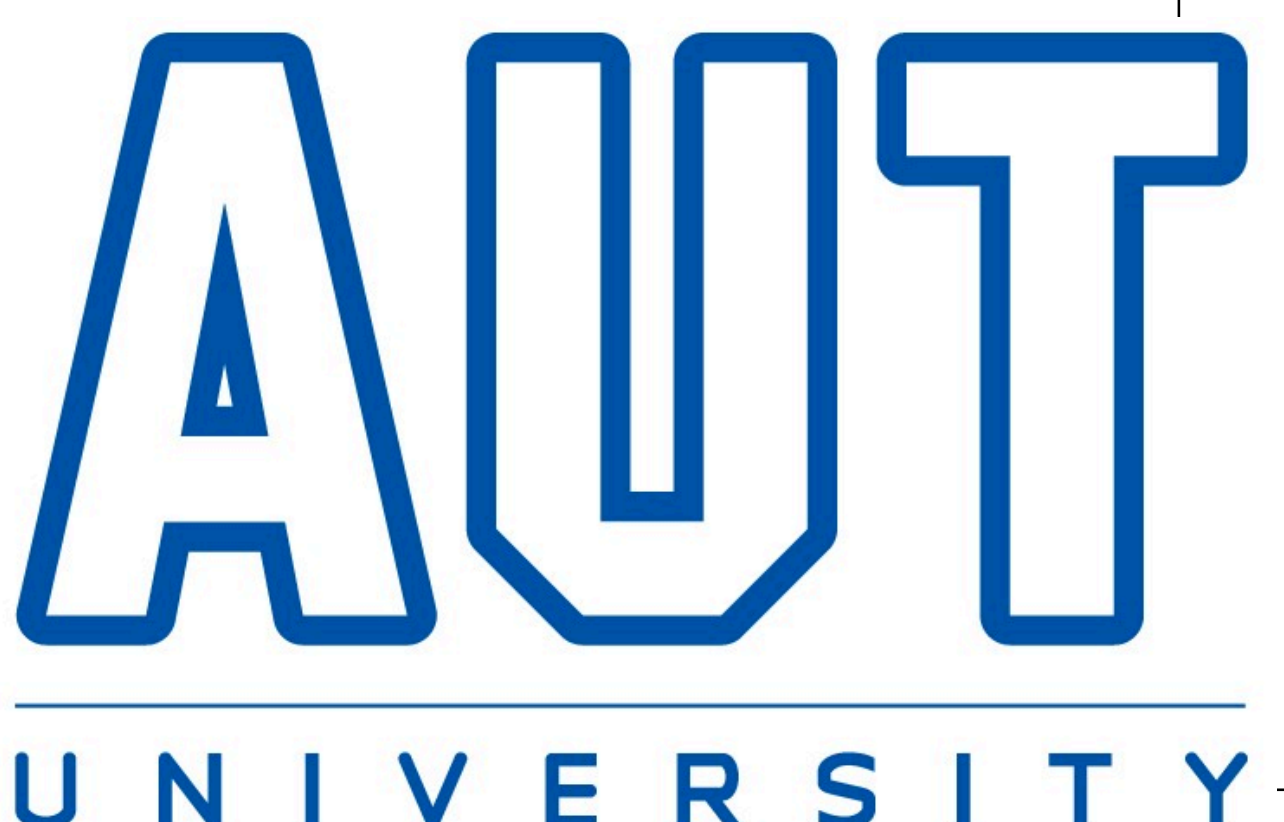

